\title{
Arenibacter troitsensis sp. nov., isolated from marine bottom sediment
}

\author{
Olga I. Nedashkovskaya, ${ }^{1}$ Makoto Suzuki, ${ }^{2}$ Mikhail V. Vysotskii ${ }^{3}$ \\ and Valery V. Mikhailov ${ }^{1}$

\begin{abstract}
${ }^{1}$ Pacific Institute of Bioorganic Chemistry of the Far-Eastern Branch of the Russian Academy of Sciences, Pr. 100 Let Vladivostoku 159, 690022, Vladivostok, Russia

${ }^{2}$ Tokyo Research Laboratories, Kyowa Hakko Kogyo Co. Ltd, 3-6-6 Asahi-machi, Machida-shi, Tokyo 194-8533, Japan

${ }^{3}$ Institute of Marine Biology of the Far-Eastern Branch of the Russian Academy of Sciences,
\end{abstract} \\ Pal'chevskogo St 17, 690032, Vladivostok, Russia
}

Correspondence

Olga I. Nedashkovskaya

olganedashkovska@piboc.dvo.ru
A novel marine, heterotrophic, aerobic, pigmented, non-motile bacterium was isolated from a bottom sediment sample collected from Troitsa Bay in the Gulf of Peter the Great, Sea of Japan, during June 2000. 16S rDNA sequence analysis revealed that this bacterium was a member of the family Flavobacteriaceae. On the basis of phenotypic, chemotaxonomic, genotypic and phylogenetic analyses, the bacterium was shown to belong to a novel species of the genus Arenibacter, for which the name Arenibacter troitsensis sp. nov. is proposed. The type strain is KMM $3674^{\top}\left(=\right.$ JCM $\left.11736^{\top}\right)$.
The genus Arenibacter was established to accommodate Gram-negative, strictly aerobic, heterotrophic, dark-orange pigmented, non-motile marine bacteria that belong to the Cytophaga-Flavobacterium-Bacteroides (CFB) phylum (Ivanova et al., 2001). Strains of the single species in this genus, Arenibacter latericius, were isolated from different sources: bottom sediments, the brown alga Chorda filum and the holothurian Apostichopus japonicus. These bacteria have been found in the South China Sea (Indian Ocean), Okhotsk Sea and Sea of Japan (Pacific Ocean). Such a wide distribution of representatives of the genus Arenibacter in different marine environments may be explained by their broad spectrum of adaptation to habitat conditions. Phylogenetically, the genus Arenibacter forms a cluster with the recently described genera Zobellia (Barbeyron et al., 2001) and Vitellibacter (Nedashkovskaya et al., 2003) and marine psychrophile ACAM 210.

In June 2000, we isolated an unknown bacterium (strain KMM $3674^{\mathrm{T}}$ ) from a marine bottom sediment sample collected at a depth of $3 \mathrm{~m}$ in Troitsa Bay in the Gulf of Peter

Published online ahead of print on 7 March 2003 as DOI 10.1099/ ijs.0.02384-0.

Abbreviations: CFB, Cytophaga-Flavobacterium-Bacteroides; JCM, Japan Collection of Microorganisms, Institute of Physical and Chemical Research (RIKEN), Wako, Japan; KMM, Collection of Marine Microorganisms of the Pacific Institute of Bioorganic Chemistry of the FarEastern Branch of the Russian Academy of Sciences, Vladivostok, Russia.

The GenBank/EMBL/DDBJ accession number for the 16S rDNA sequence of Arenibacter troitsensis KMM $3674^{\top}$ is AB080771. the Great, Sea of Japan. Polyphasic taxonomic study of the phenotypic, chemotaxonomic and genotypic characteristics and phylogenetic position of strain KMM $3674^{\mathrm{T}}$ cultured on Marine Agar 2216 (Difco) that is presented in this work indicates that this isolate is a member of the family Flavobacteriaceae and belongs to a novel species of the genus Arenibacter, for which the name Arenibacter troitsensis sp. nov. is proposed.

Flexirubin pigments were determined by the method of Fautz \& Reichenbach (1980). Degradation of alginic acids $(1 \%, w / v)$ and agar $(1.5 \%, w / v)$, growth at different temperatures, $\mathrm{NaCl}$ concentrations or $\mathrm{pH}$, production of acid from carbohydrates and hydrolysis of starch, casein, chitin, gelatin, cellulose (CM-cellulose and filter paper), DNA and urea were carried out according to Smibert \& Krieg (1994). To examine carbon source utilization, a medium that contained $0.2 \mathrm{~g} \mathrm{NaNO}_{3}, 0.2 \mathrm{~g} \mathrm{NH}_{4} \mathrm{Cl}, 0.05 \mathrm{~g}$ yeast extract (Difco) and $0.4 \%(\mathrm{w} / \mathrm{v})$ carbon source $(1 \text { artificial sea water })^{-1}$ was used. Carbon sources tested were arabinose, glucose, lactose, mannose, sucrose, inositol, sorbitol, mannitol, fumarate, citrate and malonate. Susceptibility to antibiotics was examined by the plate diffusion method. Discs were impregnated with the following antibiotics: ampicillin $(10 \mu \mathrm{g})$, benzylpenicillin $(10 \mu \mathrm{g})$, carbenicillin $(100 \mu \mathrm{g})$, gentamicin $(10 \mu \mathrm{g})$, kanamycin $(30 \mu \mathrm{g})$, lincomycin $(15 \mu \mathrm{g})$, neomycin $(30 \mu \mathrm{g})$, oleandomycin $(15 \mu \mathrm{g})$, polymyxin B (300 U), streptomycin $(10 \mu \mathrm{g})$ and tetracycline $(30 \mu \mathrm{g})$.

To determine whole-cell fatty acid profiles, bacteria were grown at $28^{\circ} \mathrm{C}$ for $48 \mathrm{~h}$ on Marine Agar 2216 (Difco). 
Analysis of fatty acid methyl esters was performed by GLC [ $30 \mathrm{~m} \times 0.25 \mathrm{~mm}$ Supelcowax 10 column (Sigma), $205^{\circ} \mathrm{C}$ ] as described by Svetashev et al. (1995). Isoprenoid quinones were extracted and analysed by the method of Nakagawa \& Yamasato (1993). Genomic DNA was isolated by the method of Marmur (1961) and the G+C content of the DNA was determined by the thermal denaturation method (Marmur \& Doty, 1962). The 16S rDNA sequence of strain KMM $3674^{\mathrm{T}}$ was determined by PCR amplification and direct sequencing (Hiraishi, 1992), using conditions and reagents that were described previously (Suzuki et al., 2001). The determined sequence was added to an alignment based on a secondary-structure model, maintained by the smallsubunit rRNA database (Van de Peer et al., 2000), by using the profile alignment program of the CLUSTAL W software (Thomson et al., 1994). Evolutionary distances were computed with the DNADIST program in the PHYLIP 3.572 package (Felsenstein, 1995) by using the Kimura twoparameter model (Kimura, 1980) and a phylogenetic tree was constructed by using the neighbour-joining method (Saitou \& Nei, 1987). To evaluate the tree, bootstrap analysis with 1000 sample replications was performed with the SEQBOOT and CONSENSE programs in the PHYLIP 3.572 package.

Strain KMM $3674^{\mathrm{T}}$ was Gram-negative, chemo-organotrophic with a respiratory type of metabolism, non-motile, nonspore-forming and occurred as single flexible rods, $0 \cdot 4-0 \cdot 7 \mu \mathrm{m}$ wide and 3-5 $\mu \mathrm{m}$ long. On Marine Agar 2216, colonies were round with entire edges, $1-3 \mathrm{~mm}$ in diameter, dark orange, low convex and shiny. The bacterium was oxidase-, catalase- and alkaline phosphatase-positive and required $\mathrm{Na}^{+}$for growth (Table 1). Growth occurred in media that contained $1-6 \% \mathrm{NaCl}$. The temperature range for growth was $10-42{ }^{\circ} \mathrm{C}$ and optimum growth occurred at $30^{\circ} \mathrm{C}$. The $\mathrm{pH}$ range for growth was $5 \cdot 5-10 \cdot 0$ and optimum growth occurred between $\mathrm{pH} 7 \cdot 5$ and $8 \cdot 5$. No flexirubin pigments were formed. Gelatin and Tween 40 were degraded. Agar, starch, alginate, DNA, cellulose (CMcellulose and filter paper), chitin, casein, urea, Tween 20, Tween 60 and Tween 80 were not hydrolysed. The organism produced $\mathrm{H}_{2} \mathrm{~S}$ but did not produce indole or acetoin (Voges-Proskauer reaction) and formed no acid from arabinose, galactose, glucose, lactose, maltose, melibiose, rhamnose, sucrose, xylose, adonitol, dulcitol, inositol or mannitol. The bacterium utilized arabinose, glucose, lactose, mannose and sucrose. Utilization of inositol, mannitol, sorbitol, citrate, fumarate and malonate as sole carbon sources was not observed. Nitrate reduction was positive. The strain was susceptible to oleandomycin, lincomycin and tetracycline and resistant to ampicillin, benzylpenicillin, carbenicillin, kanamycin, streptomycin, gentamicin, neomycin and polymyxin B. Predominant cellular fatty acids were straight-chain saturated and monounsaturated or branched-chain saturated and unsaturated fatty acids, namely $\mathrm{C}_{15: 0}(29 \cdot 0 \%), \mathrm{C}_{16: 1} \omega 7(9 \cdot 6 \%)$, $\mathrm{i}-\mathrm{C}_{15: 0}(8 \cdot 5 \%), \mathrm{i}-\mathrm{C}_{15: 1}(18 \cdot 1 \%)$ and $\mathrm{i}-\mathrm{C}_{17: 1}(5 \cdot 8 \%)$. The major isoprenoid quinone was MK-6. The $\mathrm{G}+\mathrm{C}$ content
Table 1. Phenotypic characteristics of Arenibacter troitsensis KMM $3674^{\top}$

Species: 1, Arenibacter troitsensis $\mathrm{KMM} 3674^{\mathrm{T}} ; 2$, Arenibacter latericius $(n=5)$. All strains were positive for: oxidase, catalase and alkaline phosphatase production; $\mathrm{Na}^{+}$requirement for growth; nitrate reduction; growth at $1-6 \% \mathrm{NaCl}$; growth at $10-42{ }^{\circ} \mathrm{C}$; susceptibility to lincomycin and oleandomycin. All strains were negative for: gliding motility; requirement for organic growth factors; flexirubin pigments; indole and acetoin production; degradation of agar, starch, alginic acids, casein, cellulose (CMcellulose and filter paper) and Tween-80; acid production from arabinose, sucrose, adonitol, dulcitol, inositol, malate, fumarate and citrate; susceptibility to kanamycin, benzylpenicillin, streptomycin, gentamicin, neomycin and polymyxin B. +, Positive; -, negative; $\mathrm{V}$, variable $(<60 \%$ of strains showed a positive reaction); $\mathrm{V}^{+},>60 \%$ of strains showed a positive reaction; $\mathrm{V}^{-},>60 \%$ of strains showed a negative reaction. The reactions of A. latericius $\mathrm{KMM} 426^{\mathrm{T}}$ are indicated in parentheses.

\begin{tabular}{|lcc|}
\hline Characteristic & $\mathbf{1}$ & $\mathbf{2}$ \\
\hline $\mathrm{H}_{2} \mathrm{~S}$ production & + & $-(-)$ \\
Degradation of: & + & $-(-)$ \\
$\quad$ Gelatin & - & $\mathrm{V}^{+}(-)$ \\
Tween 20 & + & $\mathrm{V}^{-}(-)$ \\
Tween 40 & - & $\mathrm{V}(-)$ \\
DNA & - & $+(+)$ \\
Urea & - & $+(+)$ \\
Growth at 8\% NaCl & & $\mathrm{V}^{+}(+)$ \\
Acid from: & - & $+(+)$ \\
Galactose & - & $\mathrm{V}^{+}(+)$ \\
Glucose, lactose & - & $\mathrm{V}^{-}(+)$ \\
Maltose, xylose & - & $\mathrm{V}^{-}(-)$ \\
Rhamnose & - & $+(+)$ \\
Mannitol & & $-(-)$ \\
Susceptibility to: & - & \\
Ampicillin, carbenicillin & + & \\
Tetracycline & &
\end{tabular}

of the DNA was $40 \cdot 0 \mathrm{~mol} \%$ (as determined by the thermal denaturation method).

To establish the precise taxonomic position of strain KMM $3674^{\mathrm{T}}$, its $16 \mathrm{~S}$ rDNA sequence $(1381 \mathrm{bp})$ was determined. Part of this determined sequence (1365 bp) was used for comparative analysis with published sequences of related representatives of the CFB phylum. Analysis revealed that strain KMM $3674^{\mathrm{T}}$ belonged phylogenetically to the family Flavobacteriaceae and formed a distinct subline within the genus Arenibacter (Fig. 1). The level of $16 \mathrm{~S}$ rDNA sequence similarity of strain KMM $3674^{\mathrm{T}}$ with strains of the single species of the genus Arenibacter, A. latericius, was $94 \cdot 9-95 \cdot 0 \%$.

Similarities in physiological characteristics and fatty acid and menaquinone compositions support the inclusion of strain KMM $3674^{\mathrm{T}}$ in the genus Arenibacter. However, strain KMM $3674^{\mathrm{T}}$ differs from the only currently described 


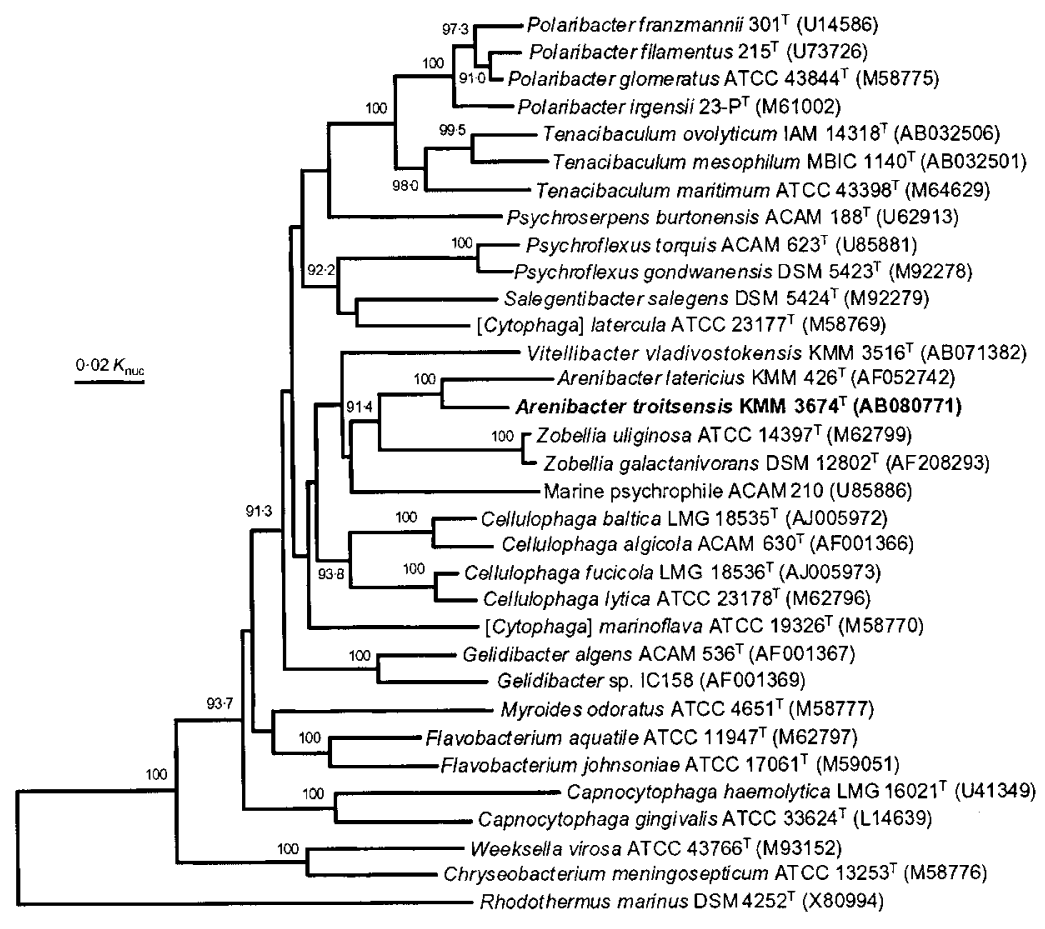

Fig. 1. Phylogenetic position of strain $\mathrm{KMM}$ $3674^{\top}$ among marine species of the family Flavobacteriaceae on the basis of $16 \mathrm{~S}$ rDNA sequence comparison. The phylogenetic tree was generated by the neighbourjoining method (Saitou \& Nei, 1987). Rhodothermus marinus (X80994) was used as the outgroup. Numbers shown next to each node indicate the percentage bootstrap value of 1000 replicates (only $70 \%$ or higher are cited). Bar, 0.02 genetic distance $\left(K_{\text {nuc }}\right)$. species of this genus, A. latericius, by positive reactions for gelatin hydrolysis and $\mathrm{H}_{2} \mathrm{~S}$ production, absence of growth at $8 \% \mathrm{NaCl}$ and urea degradation, lack of acid formation from carbohydrates, resistance to ampicillin and carbenicillin and susceptibility to tetracycline, as shown in Table 1. According to Stackebrandt \& Goebel (1994), strains may belong to a separate species if their 16S rDNA sequences differ by $>3 \%$, i.e. they have $<97 \%$ sequence similarity. The divergence of the $16 \mathrm{~S}$ rDNA sequences of strain $\mathrm{KMM} 3674^{\mathrm{T}}$ and the type strain of A. latericius, $\mathrm{KMM}$ $426^{\mathrm{T}}$, is $5 \%$. The DNA G $+\mathrm{C}$ contents of KMM $3674^{\mathrm{T}}$ and A. latericius strains are $40 \cdot 0$ and $37 \cdot 5-38 \cdot 2 \mathrm{~mol} \%$, respectively. The phenotypic features mentioned (Table 1), in association with molecular differences, allow the differentiation of strain KMM $3674^{\mathrm{T}}$ from strains of $A$. latericius.

Thus, we propose that strain KMM $3674^{\mathrm{T}}$ should be placed in the genus Arenibacter as Arenibacter troitsensis sp. nov.

\section{Description of Arenibacter troitsensis sp. nov.}

Arenibacter troitsensis (tro.it.sen'sis. N.L. adj. troitsensis referring to Troitsa Bay, from where the organism was isolated).

Cells are Gram-negative, strictly aerobic with respiratory metabolism, chemo-organotrophic, non-motile and asporogenic rods, $0 \cdot 4-0 \cdot 7 \mu \mathrm{m}$ wide and $3-5 \mu \mathrm{m}$ long. Oxidase-, catalase- and alkaline phosphatase-positive. Colonies are circular, low convex, shiny with entire edges and $1-3 \mathrm{~mm}$ in diameter on Marine Agar 2216. Dark orange, non-diffusible pigments are produced. No growth is observed without $\mathrm{Na}^{+}$. Growth occurs at $1-6 \% \mathrm{NaCl}$. Flexirubin pigments are absent. Growth occurs at $10-42^{\circ} \mathrm{C}$. Gelatin and Tween
40 are degraded. Agar, casein, starch, alginic acids, cellulose (CM-cellulose and filter paper), chitin, urea, Tween-20 and Tween-80 are not hydrolysed. No acid is formed from arabinose, galactose, glucose, lactose, maltose, melibiose, rhamnose, sucrose, xylose, adonitol, dulcitol, glycerol, inositol or mannitol. Arabinose, glucose, lactose, mannose and sucrose are utilized as sole sources of carbon and energy. Utilization of inositol, mannitol, sorbitol, citrate, fumarate and malonate is not observed. Nitrate reduction and $\mathrm{H}_{2} \mathrm{~S}$ production are positive. Indole and acetoin (VogesProskauer reaction) are not produced. Susceptible to oleandomycin, lincomycin and tetracycline. Resistant to ampicillin, carbenicillin, kanamycin, benzylpenicillin, neomycin, streptomycin, gentamicin and polymyxin $B$. Predominant cellular fatty acids are $\mathrm{C}_{15: 0}, \mathrm{i}-\mathrm{C}_{15: 1}, \mathrm{i}-\mathrm{C}_{15: 0}$, $\mathrm{C}_{16: 1} \omega 7$ and $\mathrm{i}-\mathrm{C}_{17: 1}$. Major isoprenoid quinone is MK-6. The $\mathrm{G}+\mathrm{C}$ content of the DNA is $40 \cdot 0 \mathrm{~mol} \%$.

The type strain is KMM $3674^{\mathrm{T}}\left(=\mathrm{JCM} 11736^{\mathrm{T}}\right)$. Isolated from a bottom sediment sample from Troitsa Bay in the Gulf of Peter the Great, Sea of Japan.

\section{Acknowledgements}

This research was supported by grants from the Ministry for Industry and Science of the Russian Federation (MIS RF) (\# 95-02/03-19) and the Biodiversity Program of the Russian Academy of Science and MIS RF, and Russian Foundation for Basic Research grant \# 02-04-49517.

\section{References}

Barbeyron, T., L'Haridon, S., Corre, E., Kloareg, B. \& Potin, P. (2001). Zobellia galactanovorans gen. nov., sp. nov., a marine species 
of Flavobacteriaceae isolated from a red alga, and classification of [Cytophaga] uliginosa (ZoBell and Upham 1944) Reichenbach 1989 as Zobellia uliginosa gen. nov., comb. nov. Int J Syst Evol Microbiol 51, 985-997.

Fautz, E. \& Reichenbach, H. (1980). A simple test for flexirubin-type pigments. FEMS Microbiol Lett 8, 87-91.

Felsenstein, F. (1995). PHYLIP (Phylogeny Inference Package) version 3.57c. Seattle: University of Washington.

Gutell, R. R., Larsen, N. \& Woese, C. R. (1994). Lessons from an evolving rRNA: $16 \mathrm{~S}$ and $23 \mathrm{~S}$ rRNA structures from a comparative perspective. Microbiol Rev 58, 10-26.

Hiraishi, A. (1992). Direct automated sequencing of $16 \mathrm{~S}$ rDNA amplified by polymerase chain reaction from bacterial cultures without DNA purification. Lett Appl Microbiol 15, 210-213.

Ivanova, E. P., Nedashkovskaya, O. I., Chun, J. \& 7 other authors (2001). Arenibacter gen. nov., new genus of the family Flavobacteriaceae and description of a new species, Arenibacter latericius sp. nov. Int J Syst Evol Microbiol 51, 1987-1995.

Kimura, M. (1980). A simple method for estimating evolutionary rates of base substitutions through comparative studies of nucleotide sequences. J Mol Evol 16, 111-120.

Marmur, J. (1961). A procedure for the isolation of deoxyribonucleic acid from microorganisms. J Mol Biol 3, 208-218.

Marmur, J. \& Doty, P. (1962). Determination of the base composition of deoxyribonucleic acid from its thermal denaturation temperature. J Mol Biol 5, 109-118.

Nakagawa, Y. \& Yamasato, K. (1993). Phylogenetic diversity of the genus Cytophaga revealed by $16 \mathrm{~S}$ rRNA sequencing and menaquinone analysis. J Gen Microbiol 139, 1155-1161.

Nedashkovskaya, O. I., Suzuki, M., Vysotskii, M. V. \& Mikhailov, V. V. (2003). Vitellibacter vladivostokensis gen. nov., sp. nov., a new member of the phylum Cytophaga-Flavobacterium-Bacteroides. Int J Syst Evol Microbiol 53, 1281-1286.

Reichenbach, H. (1992). The order Cytophagales. In The Prokaryotes, vol. 4, pp. 3631-3675. Edited by A. Balows, H. G. Trüper, M. Dworkin, W. Harder \& K.-H. Schleifer. New York: Springer.

Saitou, N. \& Nei, M. (1987). The neighbor-joining method: a new method for reconstructing phylogenetic trees. Mol Biol Evol 4, 406-425.

Smibert, R. M. \& Krieg, N. R. (1994). Phenotypic characterization. In Methods for General and Molecular Bacteriology, pp. 607-655. Edited by P. Gerhardt, R. G. E. Murray, W. A. Wood \& N. R. Krieg. Washington, DC: American Society for Microbiology.

Stackebrandt, E. \& Goebel, B. M. (1994). Taxonomic note: a place for DNA-DNA reassociation and 16S rRNA sequence analysis in the present species definition in bacteriology. Int J Syst Bacteriol 44, 846-849.

Suzuki, M., Nakagawa, Y., Harayama, S. \& Yamamoto, S. (2001). Phylogenetic analysis and taxonomic study of marine Cytophaga-like bacteria: proposal for Tenacibaculum gen. nov. with Tenacibaculum maritimum comb. nov. and Tenacibaculum ovolyticum comb. nov., and description of Tenacibaculum mesophilum sp. nov. and Tenacibaculum amylolyticum sp. nov. Int J Syst Evol Microbiol 51, $1639-1652$.

Svetashev, V. I., Vysotskii, M. V., Ivanova, E. P. \& Mikhailov, V. V. (1995). Cellular fatty acids of Alteromonas species. Syst Appl Microbiol 18, 37-43.

Thompson, J. D., Higgins, D. G. \& Gibson, T. J. (1994). CLUSTAL W: improving the sensitivity of progressive multiple sequence alignment through sequence weighting, position-specific gap penalties and weight matrix choice. Nucleic Acids Res 22, 4673-4680.

Van de Peer, Y., De Rijk, P., Wuyts, J., Winkelmans, T. \& De Wachter, R. (2000). The European small subunit ribosomal RNA database. Nucleic Acids Res 28, 175-176. 